\title{
The role of long non-coding RNAs in genome formatting and expression
}

\author{
Pierre-Olivier Angrand, Constance Vennin, Xuefen Le Bourhis and Eric Adriaenssens* \\ Cell Plasticity and Cancer - Inserm U908, University of Lille, Lille, France
}

Long non-coding RNAs (IncRNAs) are transcripts without protein-coding potential but having a pivotal role in numerous biological functions. Long non-coding RNAs act as regulators at different levels of gene expression including chromatin organization, transcriptional regulation, and post-transcriptional control. Misregulation of IncRNAs expression has been found to be associated to cancer and other human disorders.

OPEN ACCESS

Edited by:

Mohammadreza Hajjari, Shahid Chamran University of Ahvaz,

Iran

Reviewed by: Venugopal Thayanithy, University of Minnesota, USA Jan-Wilhelm Kornfeld,

Max-Planck Institute for Neurological Research, Germany

Maryam Tahmasebi Birgani,

Ahvaz Jundishapur University

of Medical Sciences, Iran

*Correspondence:

Eric Adriaenssens,

Cell Plasticity and Cancer - Inserm U908, University of Lille, Bâtiment SN3, Cité Scientifique, F-59655, Villeneuve d'Ascq, Lille, France eric.adriaenssens@univ-lille1.fr

Specialty section:

This article was submitted to

$R N A$,

a section of the journal

Frontiers in Genetics

Received: 28 February 2015

Paper pending published:

16 March 2015

Accepted: 12 April 2015

Published: 29 April 2015

Citation:

Angrand $P-O$, Vennin $C$, Le Bourhis $X$ and Adriaenssens $E$ (2015) The role of long non-coding RNAs in genome

formatting and expression.

Front. Genet. 6:165.

doi: 10.3389/fgene.2015.00165
Here, we review the different types of IncRNAs, their mechanisms of action on genome formatting and expression and emphasized on the multifaceted action of the $\mathrm{H} 19$ IncRNA.

\section{Keywords: IncRNAs, H19, chromatin organization, transcriptional regulation, post-transcriptional control}

The advent of DNA tilling arrays and deep sequencing technologies has revealed that a much larger part of the genome is transcribed into RNAs than previously assumed. It is estimated that up to $70 \%$ of the genome is transcribed but only $2 \%$ of the human genome codes for proteins (Bertone et al., 2004; Birney et al., 2007; Kapranov et al., 2007; ENCODE Project Consortium, 2012) and RNAs without coding potential are collectively referred as non-coding RNAs (ncRNAs).

Non-coding RNAs include the well-known ribosomal (r) RNAs, ribozymes, transfer (t) RNAs, small nuclear (sn) RNAs, telomere-associated RNAs (TERRA, TERC), as well as a plethora of far less characterized RNAs. Based on their size, these ncRNAs are subdivided into two groups: small ncRNAs $(<200 \mathrm{nt})$ and long ncRNAs [ $\operatorname{lncRNA}(>200 \mathrm{nt})]$. Small ncRNAs, such as microRNAs (miRs), small interfering RNAs (siRNAs), or PIWI-interacting RNAs (piRNAs) received much attention and were shown to mainly act as negative regulators of gene expression. In contrast, lncRNAs represent a more functionally diverse class of transcripts. LncRNAs are found in a large diversity of animals species (Guttman et al., 2009; Jia et al., 2010; Pauli et al., 2012), but also in plants (Swiezewski et al., 2009), yeast (Houseley et al., 2008), and even in prokaryotes (Bernstein et al., 1993) and viruses (Reeves et al., 2007). LncRNAs remains poorly conserved among species (Pang et al., 2006; Derrien et al., 2012). However, accumulating evidences indicate that this RNA class plays an important role in a variety of biological processes and may be involved in cancer and other human diseases (Wapinski and Chang, 2011; Tano and Akimitsu, 2012).

Majority of lncRNAs are $5^{\prime}$ capped, $3^{\prime}$ polyadenylated, multi-exonic and are subjected to transcriptional regulation as coding mRNAs (Carninci et al., 2005; Guttman et al., 2010; Cabili et al., 2011; Derrien et al., 2012). Some of the IncRNAs such as XIST, MALAT1, or NEAT1 are almost exclusively localized in the nucleus (Brown et al., 1992; Hutchinson et al., 2007), whereas others are mostly found in the cytoplasm (Coccia et al., 1992; Yoon et al., 2012). In term of genomic organization, lncRNAs can be classified according to their proximity to protein coding genes into five categories: sense, when overlapping one or more exons of another transcript; antisense, when overlapping one or more exons of another transcript on the opposite strand; bidirectional, when its expression and the expression of the neighboring coding transcript on the opposite strand are initiated in close proximity; intronic, when raising from an intron of another transcript; or intergenic, when produced from an independent transcription unit in the interval between two protein coding 
genes. This crude classification illustrates that lncRNA expression may be controlled by different molecular mechanisms, but it does account neither for their modes of action nor for their cellular functions.

While only a limited number of lncRNAs has been studied, numerous evidences indicate that lncRNAs interact with a plethora of proteins. Furthermore, homologous Watson-Crick base pairing provides an efficient way by which lncRNAs may selectively interact with other nucleic acid species. It is believed that lncRNAs are involved in a diversity of cellular functions through gene expression regulation at different levels including chromatin organization, transcriptional regulation, and post-transcriptional mRNA processing (Mercer et al., 2009; Wilusz et al., 2009).
To complicate matters further, Anderson et al. (2015) recently described that a conserved micropeptide is encoded by a skeletal muscle-specific RNA previously annotated as a putative long non-coding RNA. This finding leads to the proposal that several lncRNAs could also have a biological function through the production of micropeptides.

\section{LncRNAs in the Control of mRNA Processing}

The ability of lncRNAs to recognize complementary sequences allows the regulation of mRNA processing at various steps, including degradation, splicing, translation, or transport (Figure 1).

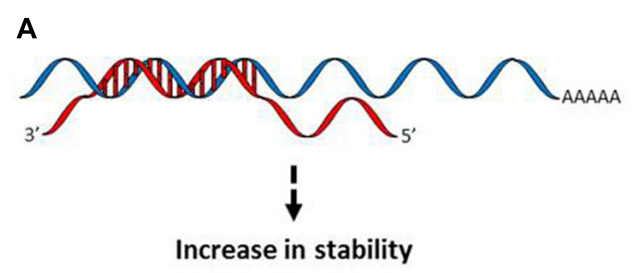

C

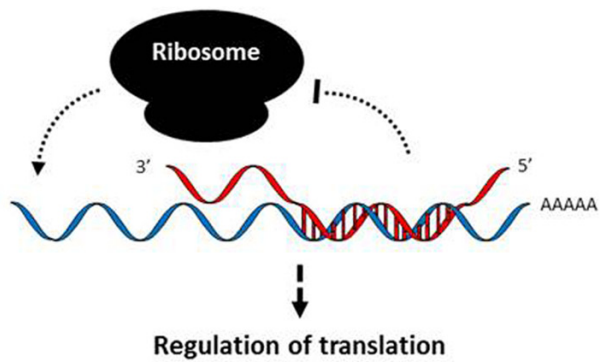

E

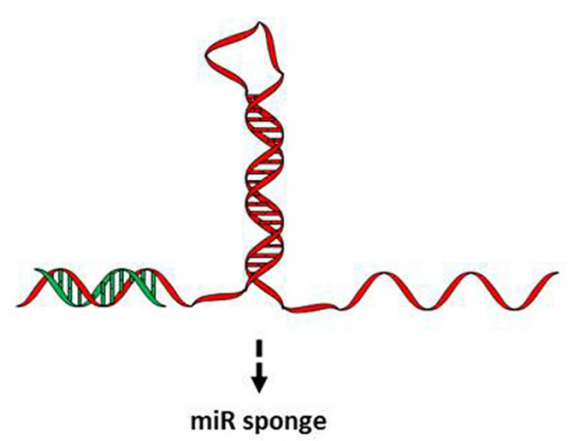

FIGURE 1 | Functional mechanisms of long non-coding (IncRNA) action at the post-transcriptional levels. (A) mRNA stabilization. Base pairing between specific regions of a long non-coding antisense RNA and its sense transcript induces stabilization of the target mRNA and increases protein abundance. (B) mRNA degradation. Staufen double-stranded RNA-binding protein 1 (STAU1)-mediated mRNA decay is induced when base pairing is formed between the mRNA and a IncRNA. (C) Ribosome targeting. Through homologous base pairing with mRNAs and interactions with ribosomal proteins
B

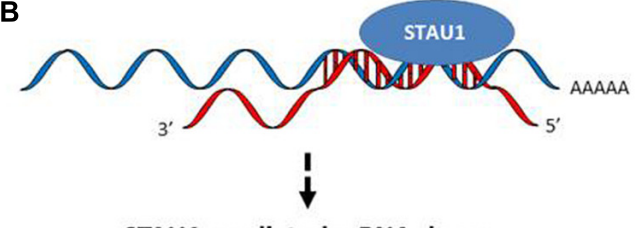

STAU1-mediated mRNA decay

D

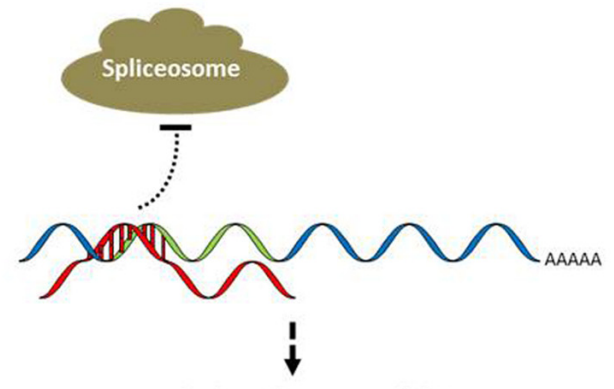

Regulation of mRNA splicing

$\mathbf{F}$

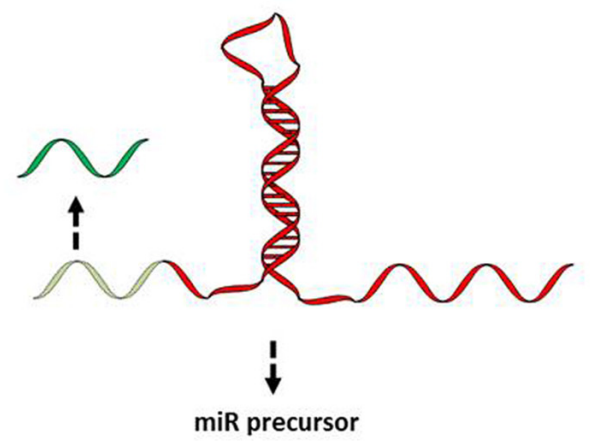

IncRNAs target transcripts to ribosomes or prevent translation. (D) Regulation of splicing. Base pairing between mRNAs and IncRNAs may prevent splicing by masking the splicing sites. In addition, IncRNAs are also implicated in the formation and maintenance of nuclear structures involved in alternative splicing of nascent transcripts. (E) miR sponge. By sequestering miRs through base pairing formations, IncRNAs affect the expression of the miR target genes. (F) Precursor of miRs. LncRNAs can serve as a source of miRs after processing. LncRNAs are shown in red, whereas mRNAs are in blue. See text for examples. 
Base pairing between defined regions of the human $\beta$-site APP-cleaving enzyme 1 (BACE1) transcript and its antisense lncRNA BACE1-AS induces the mRNA stabilization and consequently the increase in BACE1 protein abundance (Faghihi et al., 2008). Similarly, the lncRNA TINCR (terminal differentiation-induced ncRNA) interacts with a range of differentiation mRNAs including FLG, LOR, ALOXE3, ALOX12B, ABCA12, CASP14, or ELOVL3, to increase their stability (Kretz et al., 2013). In contrast, the recognition of mRNAs by other lncRNAs, such as half-STAU1-binding site RNAs (1/2sbsRNAs) decrease target mRNA stability by inducing STAU1 recruitment and the STAU1-mediated mRNA decay pathway (Gong and Maquat, 2011).

The translational process may also be modulated positively or negatively by lncRNA-mRNA pairing. For example, the antisense lncRNA ULCH-AS1 (ubiquitin carboxy-terminal hydrolase L1 antisense RNA 1) enhances ULCH mRNA translation (Carrieri et al., 2012), whereas lincRNA-p21 or pseudoNOS suppress target mRNA translation (Korneev et al., 1999; Yoon et al., 2012).

The lncRNA MALAT1 (metastasis associated lung adenocarcinoma transcript 1) regulates pre-mRNA alternative splicing by modulating active serine/arginine splicing factors levels (Tripathi et al., 2010). In this case, the modulation of the mRNA processing is not achieved by a lncRNA-mRNA pairing mechanism but rather by the MALAT1-mediated modulation of the distribution of various splicing factors in nuclear speckle domains. However, antisense transcripts may also affect alternative splicing of their sense transcripts by virtue of masking splice sites by base complementarity (Krystal et al., 1990; Khochbin et al., 1992; Beltran et al., 2008). For example, a specific isoform of the lncRNA NPPA-AS is capable of down-regulating the intron-retained NPPA (atriuretic peptide precursor A) mRNA variant through RNA duplex formation between the sense and antisense transcripts (Annilo et al., 2009).

\section{LncRNAs and the Connection with the MicroRNA World}

Some lncRNAs act on post-transcriptional regulation through the modulation of the microRNA (miR) pathways. MiRs, a large class of small ncRNA, function by annealing to complementary sites in the coding sequences or $3^{\prime}$-untranslated regions (UTRs) of target mRNAs where they favor the recruitment of protein factors that impair translation and/or promote transcript degradation leading to a decrease in protein abundance (Baek et al., 2008; Bartel, 2009). Specifically, one mechanism by which the BACE1-AS IncRNA enhances BACE1 sense mRNA stability could be by masking the binding site for miR-485-5p (Faghihi et al., 2010). Rather than competing for miR-binding sites, a number of lncRNAs contain miR-binding sites in their sequence and therefore act as "sponges" to sequester miRs away from their mRNA targets. The pseudogene PTENP1 previously considered as biologically inactive was found to sequester miRs, consequently affecting their action on target gene regulation (Poliseno et al., 2010). In particular, the $3^{\prime}$-UTR of the PTENP1
lncRNA binds the same set of miRs targeting the tumor suppressor gene PTEN, then reducing the downregulation of this transcript and thus enhancing PTEN protein abundance. A number of other lncRNAs, including KRASP1, linc-MD1, HULC, or linc-ROR were shown to control mRNA activity through a miR sponge mechanism (Poliseno et al., 2010; Wang et al., 2010, 2013; Cesana et al., 2011). These examples illustrate that lncRNAs could counteract miR actions, but lncRNAs can themselves give rise to miRs and thus favor post-translational control by miR pathways as it is the case for the mouse Dlk1Dio3 cluster or the BIC lncRNA (Eis et al., 2005; Hagan et al., 2009). Within the Dlk1-Dio3 cluster, Meg3/Gtl2 contains in its last intron the evolutionarily conserved microRNA miR-770 whereas Meg8 transcripts have the intron-encoded miR-341, miR-1188, and miR-370. Similarly, miR-155 is processed from sequences present in BIC lncRNA that accumulates in lymphoma cells.

\section{LncRNAs in the Transcriptional Control}

A number of evidences indicate that lncRNAs can act at the level of transcription either negatively or positively through a variety of molecular mechanisms (Figure 2). The dihydrofolate reductase (DHFR) gene contains a major and a minor promoter. The minor promoter gives rise to a lncRNA that forms a stable triplex lncRNA-DNA association at the major DHFR promoter and interacts with the general transcription factor II B (TFIIB) leading to the dissociation of the transcriptional preinitiation complex at this major promoter and then reducing DHFR expression (Martianov et al., 2007).

Other lncRNAs act as decoys to negatively control transcription by titrating transcription factors away from their cognate promoters. The lncRNA PANDAR (promoter of CDKN1A antisense DNA damage activated RNA) is induced in a TP53dependent manner and inhibits apoptotic gene expression to favor cell-cycle arrest through direct interaction with, and sequestration of NFYA, a transcription factor controlling the apoptotic program upon DNA damage (Hung et al., 2011). Similarly, the lncRNA GAS5 (growth arrest-specific 5) contains an RNA motif derived from a stem-loop structure mimicking a DNA motif corresponding to the glucocorticoid response element. GAS5 binds to the DNA-binding domain of the glucocorticoid receptor, acts as a decoy glucocorticoid response element and is thus competing with DNA sites for binding to the glucocorticoid receptor (Kino et al., 2010).

Rather than acting as molecular decoys, lncRNA could modulate transcription by recruiting factors at target gene promoters or acting as transcription factor co-activators. For example, a lncRNA produced at the $5^{\prime}$ regulatory region of the cyclin D1 (CCND1) gene in response to genotoxic stress tethers and modulates the activity of the RNA-binding protein TLS (translocated in liposarcoma) which in turn inhibits the activity of the histone acetyltransferases CBP (CREB binding protein) and EP300, leading to CCND1 transcriptional repression (Wang et al., 2008). The lncRNA Evf-2 (DLX6-AS1) forms a stable complex with the homeodomain-containing protein DLX2 to induce expression of 


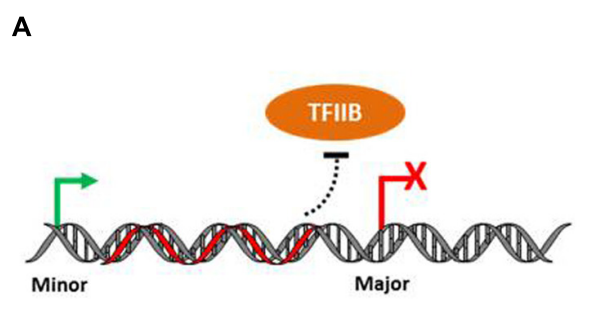

C

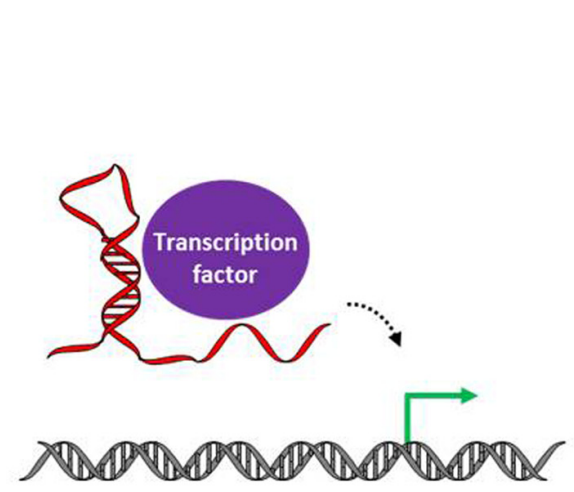

FIGURE 2 | Functional mechanism of action at the levels of transcriptional regulation. (A) LncRNA may regulate transcription by virtue of RNA-DNA triplex formation preventing the formation of the transcription initiation complex at promoters. (B) LncRNAs can act as decoys by titrating
B

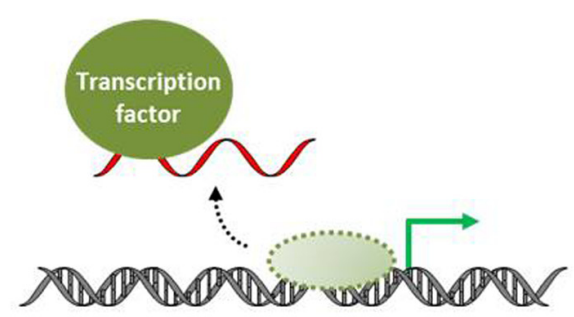

D

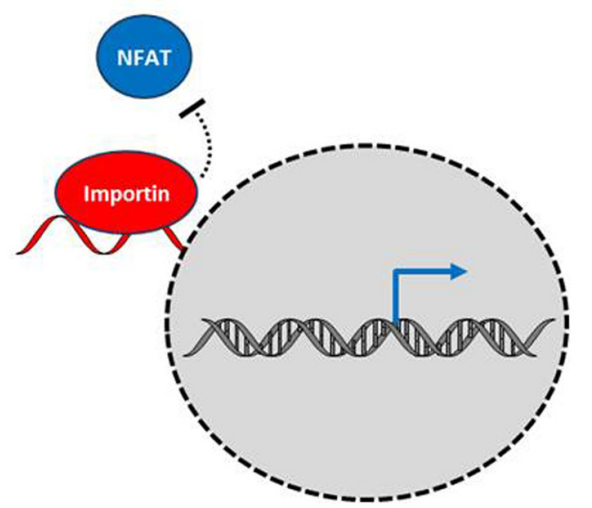

transcription factors away from their cognate promoters. (C) LncRNAs can regulate transcription through the targeting of transcription factors to promoters or acting as co-factors involved in transcription factor activity. (D) LncRNA can also control transcription factor trafficking. LncRNAs are shown in red. the adjacent genes at the DLX5/6 locus (Feng et al., 2006). In this later case, the Evf-2 lncRNA functions as a co-factor regulating transcription factor activity.

Other lncRNAs regulate transcription by controlling transcription factor trafficking. As such, the lncRNA NRON (non-protein coding RNA, repressor of NFAT) interacts with importin-beta family members to inhibit nuclear translocation of the inactive dephosphorylated nuclear factor of activated T cells (NFAT) trans-activator (Willingham et al., 2005).

\section{LncRNAs and Epigenetics}

LncRNAs have been implicated in the control of gene expression through the recruitment of epigenetic modifiers at specific genomic loci. In eukaryotic chromatin, epigenetic regulation is conveyed by covalent modifications of DNA (methylation, hydroxymethylation), modifications of histone tails (acetylation, methylation, phosphorylation, ubiquitinylation), and the incorporation of various histone variants. These modifications locally change chromatin organization and regulate gene expression without changes in the DNA sequence. A number of evidences indicate that lncRNAs, acting as guides targeting enzymes involved in chromatin modifications, are part of this picture (Figure 3).

The lncRNA HOTAIR (HOX transcript antisense RNA) is transcribed from the HOXC locus and targets Polycomb
Repressive Complex 2 (PRC2) to silence distantly located genes, including genes at the HOXD locus and 100s of other genes on various chromosomes (Rinn et al., 2007; Zhang et al., 2015). Components of PRC2 trimethylate lysine 27 of histone H3 (H3K27me3) establishing the silent chromatin state (Völkel and Angrand, 2007; Völkel et al., 2015). Interestingly, HOTAIR also binds the LSD1-CoREST complex which possesses a lysine 4 of histone $\mathrm{H} 3$ demethylase activity, thus removing an active H3K4me2 chromatin mark (Tsai et al., 2010). Furthermore, deletion analysis of HOTAIR revealed that distinct parts of the lncRNA interact with PRC2 and LSD1 indicating that HOTAIR is able to bridge two independent chromatin modifying activities at a target locus. Indeed, the knockdown of HOTAIR is responsible for the concomitant loss of occupancy of PRC2 and LSD1, and concurrent loss of $\mathrm{H} 3 \mathrm{~K} 27 \mathrm{me} 3$ and gain of $\mathrm{H} 3 \mathrm{~K} 4 \mathrm{me} 2$ at target loci. Then, HOTAIR acts as an RNA scaffold targeting two different histone modification activities involved in heterochromatin formation.

The interplay between one lncRNA and different chromatin modifying complexes is also found at the INK4A tumorsuppressor locus. The antisense lncRNA ANRIL (antisense noncoding RNA in the INK4 locus, CDKN2B-AS) which is produced by the INK4B/ARF/INK4A locus binds specifically two Polycomb proteins, CBX7 (PRC1) and SUZ12 (PRC2). Disruption of interaction with both PRC1 and PRC2 proteins impacts the transcriptional repression at the INK4B locus in cis (Yap et al., 2010; Kotake et al., 2011). As another example, the lncRNA 
A

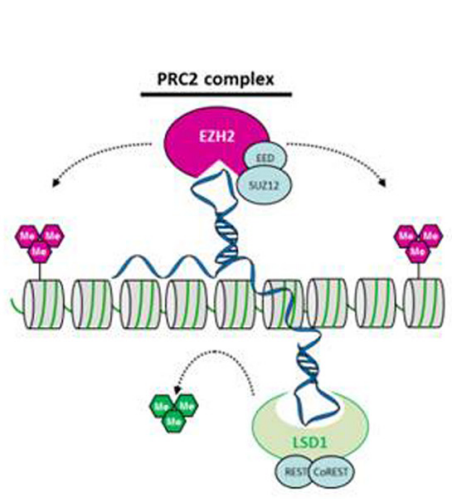

B

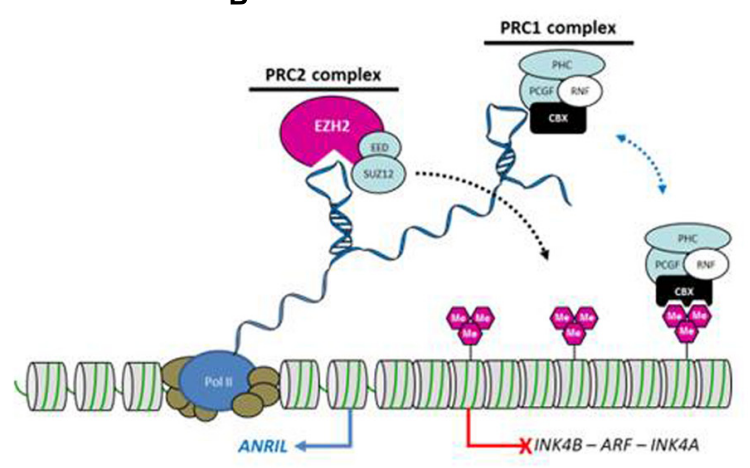

C

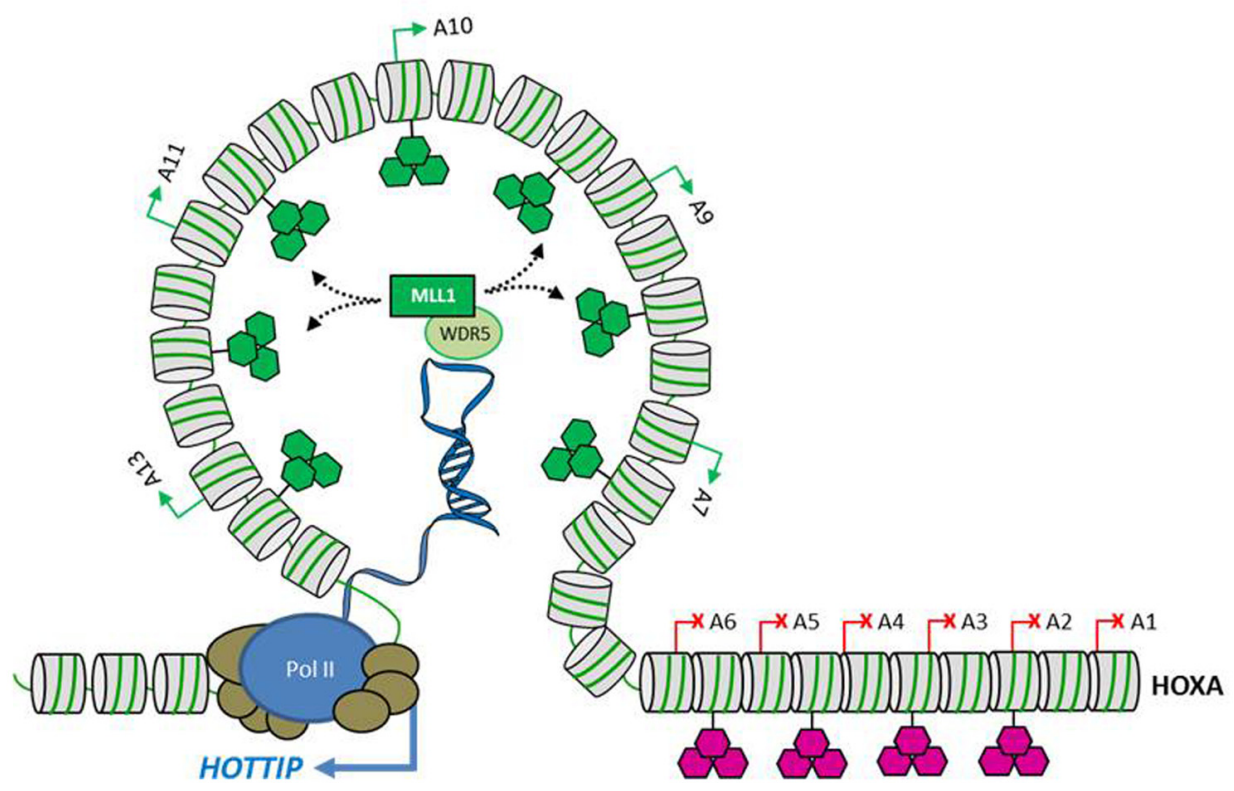

FIGURE 3 | Examples of IncRNAs controlling chromatin organization. (A) HOTAIR (HOX transcript antisense RNA) represses transcription in trans by recruiting two different chromatin modifying activities. The Polycomb Repressive Complex 2 (PRC2) produces the repressive H3K27me3 marks, whereas the LSD1-CoREST complex is responsible for the removal of the active $\mathrm{H} 3 \mathrm{~K} 4 \mathrm{me} / 3$ marks. (B) The ANRIL IncRNA represses transcription in cis at the INK4B/ARF/NK4A locus by recruiting the Polycomb repressive complexes PRC1 and PRC2. (C) The HOTTIP (HOXA transcript at the distal tip) IncRNA activates genes by recruiting the histone modifier complex WDR5-MLL which is responsible for H3K4me3 methylation, and by mediating long-range chromatin looping at one extremity of the HOXA locus. Purple hexagons represent H3K27me3 repressive marks, whereas green hexagons illustrate H3K4me3 activating marks.
KCNQ1OT1 (KCNQ1 opposite strand/antisense transcript 1) mediates bidirectional silencing by interacting with chromatin and recruiting the PRC2 complex, as well as the histone methyltransferase G9a (EHMT2), resulting in an increase in the repressive histone modifications $\mathrm{H} 3 \mathrm{~K} 27 \mathrm{me} 3$ and $\mathrm{H} 3 \mathrm{~K} 9 \mathrm{me} 3$ at the KCNQ1 domain (Pandey et al., 2008). Thus, similar to HOTAIR and ANRIL, KCNQ1OT1 represents a prototype of a scaffold RNA recruiting multiple sets of chromatin modifying activities involved in target gene silencing. Approximately 20\% of lncRNAs, including HOTAIR, ANRIL, KCNQ1OT1, but also XIST, RepA, HEIH, PCAT-1, H19, or linc-UBC1 (Zhao et al., 2008; Maenner et al., 2010; Prensner et al., 2011; Yang et al., 2011; Luo et al., 2013; He et al., 2013), are believed to guide PRC2 activity to target genes, indicating that lncRNA-mediated targeting of PRC2 at chromatin is a widely used strategy to repress gene expression through a chromatin reorganization mechanism (Khalil et al., 2009).

In contrast, the lncRNA HOTTIP (HOXA transcript at the distal tip) mediates transcriptional activation by controlling chromatin modification and organization (Wang et al., 2011). HOTTIP is produced from the $5^{\prime}$-end of the HOXA locus, downstream of HOXA13. The knockdown of HOTTIP decreases expression of HOXA genes in cis, with an efficacy that correlates with the proximity of the HOXA genes relative to the HOTTIP 


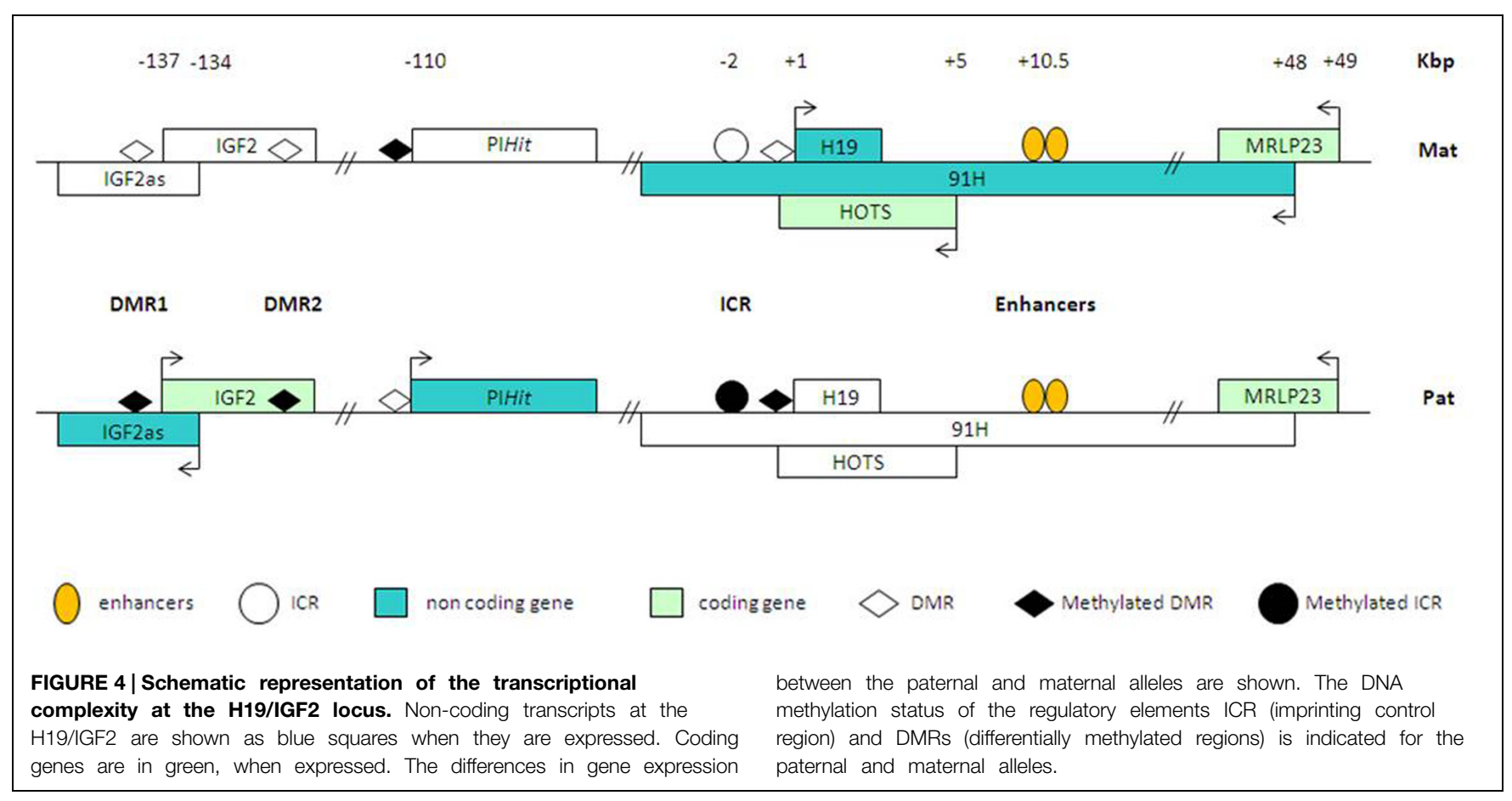

transcriptional unit. At the target genes, knockdown of HOTTIP results in the loss of activating H3K4me3 and H3K4me2 epigenetic marks, together with the decreases in occupancy of the MLL1 protein complex responsible for the establishment of these histone modifications. Furthermore, chromosome conformation capture carbon copy (C5) assays revealed abundant long-range looping interactions, bridging the transcribed target HOXA genes into proximity of the HOTTIP transcriptional unit. Thus, the mechanism by which the lncRNA HOTTIP controls HOXA expression relies on its potential to guide the histone methyltransferase MLL1 at target HOXA gene promoters, and on the formation of chromatin loops that connect distantly expressed HOXA genes to HOTTIP transcripts.

A role of lncRNAs in chromatin loop formation has also been described for the lncRNA CCAT1-L (Xiang et al., 2014). Indeed, CCAT1-L, is transcribed from a locus upstream of MYC and plays a role in MYC transcriptional regulation by promoting long-range chromatin looping.

Thus, IncRNAs, through the recruitment of chromatin modifiers and/or the induction of chromatin loops will modulate the chromatin conformation and will format the genome in a particular configuration. This IncRNA-mediated genome formatting emerges as a crucial and fundamental mechanism by which lncRNA may act on gene expression programs.

\section{H19, a Prototype of a Multitask IncRNA}

As discussed above, lncRNAs can regulate genome expression through different molecular mechanisms. However, several lncRNAs use multiple strategies that, in combination, may be required for their biological function. The action of the lncRNA H19 on gene expression illustrates the complexity of the combinatorial mechanisms of regulation achieved by a single lncRNA. H19 was the first lncRNA discovered (Brannan et al., 1990). Furthermore, H19 and its neighboring IGF2 gene located at position 11p15.5 are subjected to genomic imprinting and the study of the gene regulation at this locus serves as a model for understanding the molecular mechanisms involved in this genomic regulation. In addition, alterations of gene expression at the H19/IGF2 locus are associated to malignancies and developmental disorders. Loss of heterozygosity including loss of imprinting could be responsible for a loss of expression or a biallelic expression of these genes. Patients suffering from Beckwith-Wiedemann syndrome (BWS, OMIM 130650; Choufani et al., 2010) exhibit a loss of H19 expression and a biallelic expression of IGF2. BWS is associated with fetal and postnatal overgrowth and increased risk of embryonic or childhood cancers such as Wilm's tumors. Loss of IGF2 expression with a biallelic H19 expression is responsible for 20 to $60 \%$ of cases of Silver-Russel syndrome (SRS, OMIM 180860; Penaherrera et al., 2010). SRS is an intrauterine growth delay associated to an altered postnatal growth with facial dysmorphia and corporal asymmetry. Numerous studies including ours indicate that H19 may play a key role in tumorigenesis and could contribute to tumor progression and aggressiveness. H19 overexpression has also been reported in various cancer tissues including breast (Adriaenssens et al., 1998; Lottin et al., 2002), bladder (Cooper et al., 1996), lung (Kondo et al., 1995), and esophageal cancers (Hibi et al., 1996). Several lines of evidence indicate that $\mathrm{H} 19$ could play a role in tumor invasion and angiogenesis. In breast cancer, the oncogenic role of H19 has been well established (Berteaux et al., 2005), even if the precise molecular mechanisms involved in tumorigenesis are not yet fully understood. 


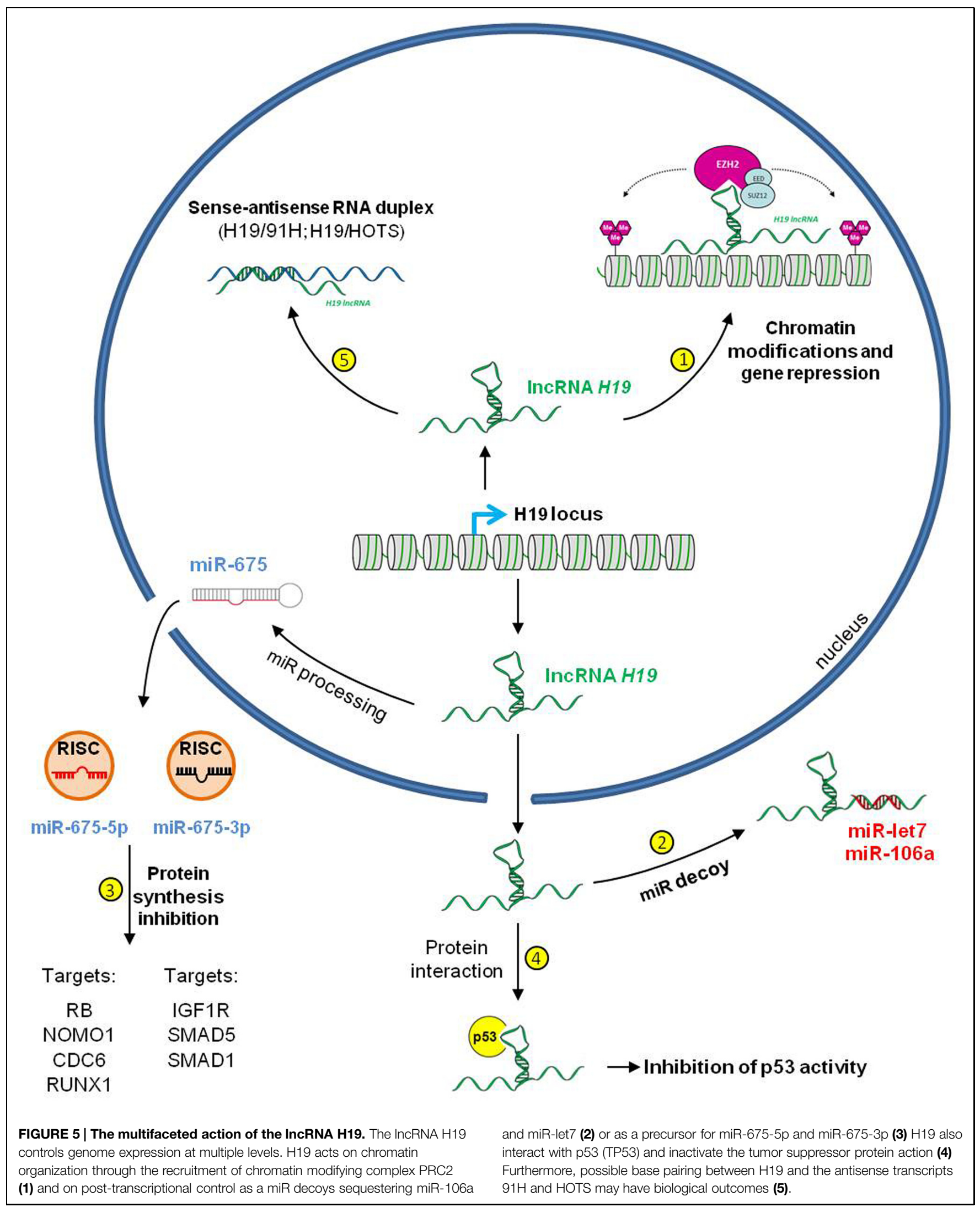


At the H19/IGF2 locus, both genes share a common set of enhancers located downstream of the H19 gene (Figure 4). The ICR (imprinting control region), located $2 \mathrm{kbp}$ upstream of the H19 promoter, controls the monoallelic expression of H19 and IGF2 by insulating communication between the $3^{\prime}$ enhancers and the IGF2 promoter. The chromatin insulator property of the H19/IGF2 ICR is regulated by the insulator CTCF (CCTC-binding factor), which binds specifically to the unmethylated maternal allele. On the paternal allele, the ICR methylation does not allow CTCF binding and leads to IGF2 expression (reviewed in Lewis and Murrell, 2004). The H19/IGF2 locus contains other differentially methylated regions (DMRs), with DMR1 being a methylation-sensitive silencer and DMR2 being a methylation-sensitive activator (Constancia et al., 2000; Murrell et al., 2004). CTCF binding to the maternal ICR regulates its interaction with matrix attachment region 3 (MAR3) and DMR1 at IGF2, thus forming a tight loop around the maternal IGF2 locus which may contribute to its silencing. These interactions restrict the physical access of distal enhancers to the IGF2 promoter (Weber et al., 2003; Murrell et al., 2004; Kurukuti et al., 2006). Furthermore, several lncRNAs are produced at the H19/IGF2 locus adding further complexity to the locus regulation. The first antisense transcript at the H19/IGF2 locus is the lncRNA IGF2-AS (3-4 kb) discovered in 1991 in chicken (Rivkin et al., 1993; Moore et al., 1997). IGF2-AS and IGF2 are coregulated at the transcriptional levels but the function of this IGF2-AS lncRNA remains unclear. The lncRNA $91 \mathrm{H}$ (about $120 \mathrm{~kb}$ ) is transcribed from the maternal allele (Berteaux et al., 2008). Recently, at the same position, a new protein coding gene HOTS (6 kbp) has been described (Onyango and Feinberg, 2011) but the relationship between the HOTS and $91 \mathrm{H}$ is still not clear. However, these two transcripts are transcribed in an antisense orientation compared to H19. An additional lncRNA produced by the H19/IGF2 locus has been identified (Court et al., 2011). This PIHit (paternally expressed IGF2/H19 intergenic transcript) lncRNA is a $5-6 \mathrm{~kb}$ transcript expressed from the paternal allele after birth. Thus, the genomic organization of coding and non-coding transcripts illustrates the complexity of the interleaved networks of lncRNAs expressed from the H19/IGF2 locus.

To complicate matters further, H19 lncRNA mechanisms of action appear to be extremely diverse, acting at various levels (Figure 5). H19 has been shown to guide chromatin modifying enzymes to specific loci. In particular, Luo et al. (2013) have shown that H19 binds to and recruit the histone methyltransferase EZH2 at the E-cadherin promoter, leading to an increase in $\mathrm{H} 3 \mathrm{~K} 27 \mathrm{me} 3$ repressive marks and to the silencing of the E-cadherin gene in bladder cancer. PRC2 protein members are not the only chromatin modifying factors interacting with $\mathrm{H} 19$ since it has been shown that this lncRNA physically binds to the methyl-CpG-binding domain protein 1 (MBD1). The H19-MBD1 complex is then recruited at several imprinted genes including IGF2, SLC38A4, and PEG1 (Monnier et al., 2013). This recruitment also induces methylation at lysine 9 of histone $\mathrm{H} 3$ (H3K9me3), probably via the additional interaction with an $\mathrm{H} 3 \mathrm{~K} 9$ histone methylransferase.

The multifaceted action of $\mathrm{H} 19$ is also illustrated by its dual interaction with miR pathways. On one hand, the lncRNA H19 acts as miR sponge to sequester miR-106a as well as the mir-let7 family members (Kallen et al., 2013; Imig et al., 2015). On the other end, H19 serves as a precursor of miR-675 that will in turn, post-translationally regulate a number of targets involved in cell tumorigenicity, including RB, IGFR1, SMAD1, SMAD5, CDC6, NOMO1, or RUNX1 (Cai and Cullen, 2007; Tsang et al., 2010; Gao et al., 2012; Keniry et al., 2012; Dey et al., 2014; Zhuang et al., 2014). The role of H19 in tumor progression could also be mediated through its interaction with the tumor-suppressor

\section{TABLE 1 | Examples of long non-coding RNAs (IncRNAs) associated with human disorders.}

\begin{tabular}{|c|c|c|c|}
\hline IncRNA & Cancer/disease & Mechanisms of action & Reference \\
\hline ANRIL & $\begin{array}{l}\text { Neurofibromatosis type 1, prostate cancer, } \\
\text { melanoma, acute lymphoblastic leukemia }\end{array}$ & $\begin{array}{l}\text { Chromatin modification via the recruitment of the } \\
\text { Polycomb Repressive Complex } 2 \text { (PRC2) at the } \\
\text { INKB/ARF/INK4A tumor suppressor locus }\end{array}$ & $\begin{array}{l}\text { Pasmant et al. (2007), Pasmant et al. (2011), Yap } \\
\text { et al. (2010), lacobucci et al. (2011) }\end{array}$ \\
\hline HOTAIR & $\begin{array}{l}\text { Hepatocellular carcinoma, colorectal } \\
\text { cancer, breast cancer, glioblastomas }\end{array}$ & $\begin{array}{l}\text { Chromatin modification via the recruitment of PRC2 } \\
\text { and LSD1 in trans. }\end{array}$ & $\begin{array}{l}\text { Gupta et al. (2010), Kogo et al. (2011), Yang et al. } \\
\text { (2011), Zhang et al. (2015) }\end{array}$ \\
\hline $\mathrm{H} 19$ & $\begin{array}{l}\text { Colorectal, gastric, breast, lung, } \\
\text { esophageal, bladder, pancreas, ovary } \\
\text { cancers }\end{array}$ & $\begin{array}{l}\text { Chromatin modification via the recruitment of } \\
\text { PRC2; Decoy for miR-Let-7; source of miR-675; } \\
\text { TP53 inactivation }\end{array}$ & $\begin{array}{l}\text { Kondo et al. (1995), Cooper et al. (1996), Hibi et al } \\
\text { (1996), Lottin et al. (2002), Berteaux et al. (2005), } \\
\text { Tsang et al. (2010), Yang et al. (2012), Luo et al. } \\
\text { (2013), Ma et al. (2014), Zhuang et al. (2014) }\end{array}$ \\
\hline $\mathrm{HEIH}$ & Hepatocellular carcinoma & Chromatin modification via the recruitment of PRC2 & Yang et al. (2011) \\
\hline PCAT-1 & Prostate cancer & Chromatin modification via the recruitment of PRC2 & Prensner et al. (2011) \\
\hline linc-UBC1 & Bladder cancer & Chromatin modification via the recruitment of PRC2 & He et al. (2013) \\
\hline BACE1-AS & Alzheimer's disease & Increase in mRNA stability & Faghihi et al. (2008) \\
\hline GAS5 & Breast, bladder cancers & $\begin{array}{l}\text { Decoy for the glucocorticoid receptor; regulation of } \\
\text { CDK6 expression }\end{array}$ & $\begin{array}{l}\text { Mourtada-Maarabouni et al. (2009), Kino et al. } \\
\text { (2010), Liu et al. (2013) }\end{array}$ \\
\hline PTENP1 & Prostate cancer & miR decoy & Poliseno et al. (2010) \\
\hline KCNA2-AS & Neuropathic pain & Decrease of KCNA2 expression & Zhao et al. (2013) \\
\hline MIAT & Schizophrenia & $\begin{array}{l}\text { Component of the nuclear matrix involved in mRNA } \\
\text { splicing }\end{array}$ & Barry et al. (2014), Ishizuka et al. (2014) \\
\hline MALAT1 & Lung cancer & Alternative splicing regulation & Schmidt et al. (2011) \\
\hline
\end{tabular}


TP53 protein. This association results in partial TP53 inactivation (Yang et al., 2012).

Several evidences also indicate that the H19 lncRNA controls IGF2 expression at the translational and/or post-translational levels ( $\mathrm{Li}$ et al., 1998), suggesting that other mechanisms by which H19 exerts its action remain to be deciphered. Similarly, the possible role of RNA duplex formation between $\mathrm{H} 19$ and the antisense transcripts $91 \mathrm{H}$ and HOTS requires investigations.

\section{LncRNAs in Human Diseases}

Given the wide range of molecular actions achieved by the lncRNAs and their roles in various physiological processes, it is not surprising that they have been shown to be involved in many human diseases. A number of data indicate that alterations of lncRNA expression lead to tumorigenesis through changes at the chromatin, transcriptional or post-transcriptional levels that impact target genes expression (Table 1). Since lncRNAs are regulating a different cellular pathways, growing evidences suggest that they could play a role in a large number of other human disorders including metabolic diseases, neurodegenerative and psychiatric disorders, cardiovascular and immune dysfunctions (Taft et al., 2010; Esteller, 2011; Harries, 2012; Shi et al., 2013; Clark and Blackshaw, 2014).

\section{Perspectives and Concluding Remarks}

LncRNAs represent a large part of the transcriptome and a very heterogeneous class of transcripts in terms of genomic organization and modes of action. Many of them are considered as key regulators of gene expression and thus, lncRNAs constitute an additional layer controlling the cellular programs. LncRNAs regulate diverse expression steps at the levels

\section{References}

Adriaenssens, E., Dumont, L., Lottin, S., Bolle, D., Leprêtre, A., Delobelle, A., et al. (1998). H19 overexpression in breast adenocarcinoma stromal cells is associated with tumor values and steroid receptor status but independent of p53 and Ki-67 expression. Am. J. Pathol. 153, 1597-1607. doi: 10.1016/S0002-9440(10) 65748-3

Aguirre, A., Montserrat, N., Zacchigna, S., Nivet, E., Hishida, T., Krause, M. N., et al. (2014). In vivo activation of a conserved microRNA program induces mammalian heart regeneration. Cell Stem Cell 15, 589-604. doi: 10.1016/j.stem.2014.10.003

Anderson, D. M., Anderson, K. M., Chang, C. L., Makarewich, C. A., Nelson, B. R., McAnally, J. R., et al. (2015). A micropeptide encoded by a putative long noncoding RNA regulates muscle performance. Cell 160, 595-606. doi: 10.1016/j.cell.2015.01.009

Annilo, T., Kepp, K., and Laan, M. (2009). Natural antisense transcript of natriuretic peptide precursor A (NPPA): structural organization and modulation of NPPA expression. BMC Mol. Biol. 10:81. doi: 10.1186/14712199-10-81

Baek, D., Villén, J., Shin, C., Camargo, F. D., Gygi, S. P., and Bartel, D. P. (2008). The impact of microRNAs on protein output. Nature 455, 64-71. doi: 10.1038 /nature 07242 of chromatin rearrangement, transcriptional control, and/or post-transcriptional processing. By these actions, lncRNAs are involved in numerous physiological functions and in many cases lncRNA alterations are associated with human disorders.

The fact that IncRNAs can be deregulated in tumors and other human pathologies, make them attractive candidates as biomarkers and as targets for therapy. LncRNAs may be downregulated at the RNA levels by targeting their sequence. As so, short interfering RNAs (siRNAs) designed to perfectly match exact stretches of nucleotides, guarantee a high degree of specificity leading to lncRNA degradation. The power of the siRNA approach is illustrated by the success of a number of preclinical studies where siRNAs targeted mRNAs (Kaur et al., 2014). Similar approaches can thus be envisioned to target non-coding RNAs. Indeed, siRNAs have also been used to target miRs, leading to heart regeneration in an in vivo mouse model (Aguirre et al., 2014) and the use of siRNAs has been proposed in a therapeutic strategy targeting the lncRNA HOTAIR in endometrial carcinoma (Huang et al., 2014). Similarly, antisense oligonucleotides, single-strand DNA, or RNA molecules of 8 to 50 nucleotides can be used to target lncRNA. Specifically, in vivo and in vitro experiments revealed that antisense oligonucleotides directed against the lncRNA MALAT1 inhibit its expression and drastically reduce lung cancer metastasis (Gutschner et al., 2013; Tripathi et al., 2013).

In this context, further exploration in the complexity of the lncRNA world promises the emergence of novel therapeutic opportunities.

\section{Acknowledgments}

This work is supported by Inserm, the University of Lille, and grants from INCa (PLBio 2010), le Comité du Nord de la Ligue Contre le Cancer and l'ITMO Biologie Cellulaire, Développement et Evolution (BCDE).

Barry, G., Briggs, J. A., Vanichkina, D. P., Poth, E. M., Beveridge, N. J., Ratnu, V. S., et al. (2014). The long non-coding RNA Gomafu is acutely regulated in response to neuronal activation and involved in schizophrenia-associated alternative splicing. Mol. Psychiatry 19, 486-494. doi: 10.1038/mp.2013.45

Bartel, D. P. (2009). MicroRNAs: target recognition and regulatory functions. Cell 136, 215-233. doi: 10.1016/j.cell.2009.01.002

Beltran, M., Puig, I., Peña, C., García, J. M., Alvarez, A. B., Peña, R., et al. (2008). A natural antisense transcript regulates Zeb2/Sip1 gene expression during Snail1-induced epithelial-mesenchymal transition. Genes Dev. 22, 756-769. doi: $10.1101 /$ gad.455708

Bernstein, H. D., Zopf, D., Freymann, D. M., and Walter, P. (1993). Functional substitution of the signal recognition particle $54-\mathrm{kDa}$ subunit by its Escherichia coli homolog. Proc. Natl. Acad. Sci. U.S.A. 90, 5229-5233. doi: 10.1073/pnas.90.11.5229

Berteaux, N., Aptel, N., Cathala, G., Genton, C., Coll, J., Daccache, A., et al. (2008). A novel H19 antisense RNA overexpressed in breast cancer contributes to paternal IGF2 expression. Mol. Cell. Biol. 28, 6731-6745. doi: 10.1128/MCB.02103-07

Berteaux, N., Lottin, S., Monté, D., Pinte, S., Quatannens, B., Coll, J., et al. (2005). H19 mRNA-like noncoding RNA promotes breast cancer cell proliferation through positive control by E2F1. J. Biol. Chem. 280, 29625-22936. doi: 10.1074/jbc.M504033200 
Bertone, P., Stolc, V., Royce, T. E., Rozowsky, J. S., Urban, A. E., Zhu, X., et al. (2004). Global identification of human transcribed sequences with genome tiling arrays. Science 306, 2242-2246. doi: 10.1126/science.1103388

Birney, E., Stamatoyannopoulos, J. A., Dutta, A., Guigó, R., Gingeras, T. R., Margulies, E. H., et al. (2007). Identification and analysis of functional elements in $1 \%$ of the human genome by the ENCODE pilot project. Nature 447, 799-816. doi: 10.1038/nature05874

Brannan, C. I., Dees, E. C., Ingram, R. S., and Tilghman, S. M. (1990). The product of the H19 gene may function as an RNA. Mol. Cell. Biol. 10, 28-36.

Brown, C. J., Hendrich, B. D., Rupert, J. L., Lafrenière, R. G., Xing, Y., Lawrence, J., et al. (1992). The human XIST gene: analysis of a $17 \mathrm{~kb}$ inactive X-specific RNA that contains conserved repeats and is highly localized within the nucleus. Cell 71, 527-542. doi: 10.1016/0092-8674(92)90520-M

Cabili, M. N., Trapnell, C., Goff, L., Koziol, M., Tazon-Vega, B., and Regev, A, et al. (2011). Integrative annotation of human large intergenic noncoding RNAs reveals global properties and specific subclasses. Genes Dev. 25, 1915-1927. doi: 10.1101/gad.17446611

Cai, X., and Cullen, B. R. (2007). The imprinted H19 noncoding RNA is a primary microRNA precursor. RNA 13, 313-316. doi: $10.1261 / \mathrm{rna}$. 351707

Carninci, P., Kasukawa, T., Katayama, S., Gough, J., Frith, M. C., Maeda, N., et al. (2005). FANTOM consortium; RIKEN genome exploration research group and genome science group (genome network project core group). The transcriptional landscape of the mammalian genome. Science 309, 1559-1563.

Carrieri, C., Cimatti, L., Biagioli, M., Beugnet, A., Zucchelli, S., Fedele S., et al. (2012). Long non-coding antisense RNA controls Uchll translation through an embedded SINEB2 repeat. Nature 491, 454-457. doi: 10.1038/nature11508

Cesana, M., Cacchiarelli, D., Legnini, I., Santini, T., Sthandier, O., Chinappi, M., et al. (2011). A long noncoding RNA controls muscle differentiation by functioning as a competing endogenous RNA. Cell 147, 358-369. doi: 10.1016/j.cell.2011.09.028

Choufani, S., Shuman, C., and Weksberg, R. (2010). Beckwith-Wiedemann syndrome. Am. J. Med. Genet. C Semin. Med. Genet. 154C, 343-354. doi: 10.1002/ajmg.c.30267

Clark, B. S., and Blackshaw, S. (2014). Long non-coding RNA-dependent transcriptional regulation in neuronal development and disease. Front. Genet. 5:164. doi: 10.3389/fgene.2014.00164

Coccia, E. M., Cicala, C., Charlesworth, A., Ciccarelli, C., Rossi, G. B., Philipson, L., et al. (1992). Regulation and expression of a growth arrest-specific gene (gas5) during growth, differentiation, and development. Mol. Cell. Biol. 12, 3514-3521.

Constancia, M., Dean, W., Lopes, S., Moore, T., Kelsey, G., and Reik, W. (2000). Deletion of a silencer element in Igf2 results in loss of imprinting independent of H19. Nat. Genet. 26, 203-206. doi: 10.1038/79930

Cooper, M. J., Fischer, M., Komitowski, D., Shevelev, A., Schulze, E., Ariel, I., et al. (1996). Developmentally imprinted genes as markers for bladder tumor progression. J. Urol. 155, 2120-2127. doi: 10.1016/S0022-5347(01) 66120-2

Court, F., Baniol, M., Hagege, H., Petit, J. S., Lelay-Taha, M. N., Carbonell, F., et al. (2011). Long-range chromatin interactions at the mouse Igf2/H19 locus reveal a novel paternally expressed long non-coding RNA. Nucleic Acids Res. 39, 5893-5906. doi: 10.1093/nar/gkr209

Derrien, T., Johnson, R., Bussotti, G., Tanzer, A., Djebali, S., Tilgner, H., et al. (2012). The GENCODE v7 catalog of human long noncoding RNAs: analysis of their gene structure, evolution, and expression. Genome Res. 22, 1775-1189. doi: $10.1101 /$ gr.132159.111

Dey, B. K., Pfeifer, K., and Dutta, A. (2014). The H19 long noncoding RNA gives rise to microRNAs miR-675-3p and miR-675-5p to promote skeletal muscle differentiation and regeneration. Genes Dev. 28, 491-501. doi: $10.1101 /$ gad.234419.113

Eis, P. S., Tam, W., Sun, L., Chadburn, A., Li, Z., Gomez, M. F., et al. (2005). Accumulation of miR-155 and BIC RNA in human B cell lymphomas. Proc. Natl. Acad. Sci. U.S.A. 102, 3627-3632. doi: 10.1073/pnas. 0500613102

ENCODE Project Consortium. (2012). An integrated encyclopedia of DNA elements in the human genome. Nature 489, 57-74. doi: 10.1038/nature11247

Esteller, M. (2011). Non-coding RNAs in human disease. Nat. Rev. Genet. 12, 861-874. doi: $10.1038 / \mathrm{nrg} 3074$
Faghihi, M. A., Modarresi, F., Khalil, A. M., Wood, D. E., Sahagan, B. G., Morgan, T. E., et al. (2008). Expression of a noncoding RNA is elevated in Alzheimer's disease and drives rapid feedforward regulation of $\beta$-secretase. Nat. Med. 14, 723-730. doi: 10.1038/nm1784

Faghihi, M. A., Zhang, M., Huang, J., Modarresi, F., Van der Brug, M. P., Nalls, M. A., et al. (2010). Evidence for natural antisense transcript-mediated inhibition of microRNA function. Genome Biol. 11, R56. doi: 10.1186/gb-2010-11-5r56

Feng, J., Bi, C., Clark, B. S., Mady, R., Shah, P., and Kohtz, J. D. (2006). The Evf2 noncoding RNA is transcribed from the Dlx-5/6 ultraconserved region and functions as a Dlx-2 transcriptional coactivator. Genes Dev. 20, 1470-1484. doi: 10.1101/gad.1416106

Gao, W. L., Liu, M., Yang, Y., Yang, H., Liao, Q., Bai, Y., et al. (2012). The imprinted H19 gene regulates human placental trophoblast cell proliferation via encoding miR-675 that targets Nodal Modulator 1 (NOMO1). RNA Biol. 9, 1002-1010. doi: $10.4161 /$ rna.20807

Gong, C., and Maquat, L. E. (2011). IncRNAs transactivate STAU1-mediated mRNA decay by duplexing with 3' UTRs via Alu elements. Nature 470, 284-288. doi: 10.1038/nature09701

Gupta, R. A., Shah, N., Wang, K. C., Kim, J., Horlings, H. M., Wong, D. J., et al. (2010). Long non-coding RNA HOTAIR reprograms chromatin state to promote cancer metastasis. Nature 464, 1071-1076. doi: 10.1038/nature0897

Gutschner, T., Hämmerle, M., Eissmann, M., Hsu, J., Kim, Y., Hung, G., et al. (2013). The noncoding RNA MALAT1 is a critical regulator of the metastasis phenotype of lung cancer cells. Cancer Res. 73, 1180-1189. doi: 10.1158/00085472.CAN-12-2850

Guttman, M., Amit, I., Garber, M., French, C., Lin, M. F., Feldser, D., et al. (2009). Chromatin signature reveals over a thousand highly conserved large non-coding RNAs in mammals. Nature 458, 223-227. doi: 10.1038/nature07672

Guttman, M., Garber, M., Levin, J. Z., Donaghey, J., Robinson, J., Adiconis, X., et al. (2010). Ab initio reconstruction of cell type-specific transcriptomes in mouse reveals the conserved multi-exonic structure of lincRNAs. Nat. Biotechnol. 28, 503-510. doi: 10.1038/nbt.1633

Hagan, J. P., O’Neill, B. L., Stewart, C. L., Kozlov, S. V., and Croce, C. M. (2009). At least ten genes define the imprinted Dlk1-Dio3 cluster on mouse chromosome 12qF1. PLoS ONE 4:e4352. doi: 10.1371/journal.pone.0004352

Harries, L. W. (2012). Long non-coding RNAs and human disease. Biochem. Soc. Trans. 40, 902-906. doi: 10.1042/BST20120020

He, W., Cai, Q., Sun, F., Zhong, G., Wang, P., Liu, H., et al. (2013). linc-UBC1 physically associates with polycomb repressive complex 2 (PRC2) and acts as a negative prognostic factor for lymph node metastasis and survival in bladder cancer. Biochim. Biophys. Acta 1832, 1528-1537. doi: 10.1016/j.bbadis.2013.05.010

Hibi, K., Nakamura, H., Hirai, A., Fujikake, Y., Kasai, Y., Akiyama, S., et al. (1996). Loss of H19 imprinting in esophageal cancer. Cancer Res. 56, 480-482.

Houseley, J., Rubbi, L., Grunstein, M., Tollervey, D., and Vogelauer, M. (2008). A ncRNA modulates histone modification and mRNA induction in the yeast GAL gene cluster. Mol. Cell 32, 685-695. doi: 10.1016/j.molcel.2008. 09.027

Huang, J., Ke, P., Guo, L., Wang, W., Tan, H., Liang, Y., et al. (2014). Lentivirus-mediated RNA interference targeting the long noncoding RNA HOTAIR inhibits proliferation and invasion of endometrial carcinoma cells in vitro and in vivo. Int. J. Gynecol. Cancer 24, 635-642. doi: 10.1097/IGC.0000000000000121

Hung, T., Wang, Y., Lin, M. F., Koegel, A. K., Kotake, Y., Grant, G. D., et al. (2011). Extensive and coordinated transcription of noncoding RNAs within cell-cycle promoters. Nat. Genet. 43, 621-629. doi: 10.1038/ ng.848

Hutchinson, J. N., Ensminger, A. W., Clemson, C. M., Lynch, C. R., Lawrence, J. B., and Chess, A. (2007). A screen for nuclear transcripts identifies two linked noncoding RNAs associated with SC35 splicing domains. BMC Genomics 8:39. doi: 10.1186/1471-2164-8-39

Iacobucci, I., Sazzini, M., Garagnani, P., Ferrari, A., Boattini, A., Lonetti, A., et al. (2011). A polymorphism in the chromosome 9p21 ANRIL locus is associated to Philadelphia positive acute lymphoblastic leukemia. Leuk. Res. 35, 1052-1059. doi: 10.1016/j.leukres.2011.02.020

Imig, J., Brunschweiger, A., Brümmer, A., Guennewig, B., Mittal, N., Kishore, S., et al. (2015). miR-CLIP capture of a miRNA targetome uncovers a lincRNA 
H19-miR-106a interaction. Nat. Chem. Biol. 11, 107-114. doi: 10.1038/nchembio. 1713

Ishizuka, A., Hasegawa, Y., Ishida, K., Yanaka, K., and Nakagawa, S. (2014). Formation of nuclear bodies by the lncRNA Gomafu-associating proteins Celf3 and SF1. Genes Cells 19, 704-721. doi: 10.1111/gtc.12169

Jia, H., Osak, M., Bogu, G. K., Stanton, L. W., Johnson, R., and Lipovich, L. (2010). Genome-wide computational identification and manual annotation of human long noncoding RNA genes. RNA 16, 1478-1487. doi: 10.1261/rna. 1951310

Kallen, A. N., Zhou, X. B., Xu, J., Qiao, C., Ma, J., Yan, L., et al. (2013). The imprinted H19 lncRNA antagonizes let-7 microRNAs. Mol. Cell 52, 101-112. doi: 10.1016/j.molcel.2013.08.027

Kapranov, P., Willingham, A. T., and Gingeras, T. R. (2007). Genome-wide transcription and the implications for genomic organization. Nat. Rev. Genet. 8, 413-423. doi: 10.1038/nrg2083

Kaur, I. P., Chopra, K., Rishi, P., Puri, S., and Sharma, G. (2014). Small RNAs: the qualified candidates for gene manipulation in diverse clinical pathologies. Crit. Rev. Ther. Drug. Carrier Syst. 31, 305-329. doi: 10.1615/CritRevTherDrugCarrierSyst.2014007943

Keniry, A., Oxley, D., Monnier, P., Kyba, M., Dandolo, L., Smits, G., et al. (2012). The H19 lincRNA is a developmental reservoir of miR-675 that suppresses growth and Igf1r. Nat. Cell Biol. 14, 659-665. doi: 10.1038/ ncb2521

Khalil, A. M., Guttman, M., Huarte, M., Garber, M., Raj, A., Rivea Morales, D., et al. (2009). Many human large intergenic noncoding RNAs associate with chromatin-modifying complexes and affect gene expression. Proc. Natl. Acad. Sci. U.S.A. 106, 11667-11672. doi: 10.1073/pnas. 0904715106

Khochbin, S., Brocard, M. P., Grunwald, D., and Lawrence, J. J. (1992). Antisense RNA and 53 regulation in induced murine cell differentiation. Ann. N. Y. Acad. Sci. 660, 77-87. doi: 10.1111/j.1749-6632.1992.tb21060.x

Kino, T., Hurt, D. E., Ichijo, T., Nader, N., and Chrousos, G. P. (2010). Noncoding RNA gas5 is a growth arrest- and starvation-associated repressor of the glucocorticoid receptor. Sci. Signal. 3:ra8. doi: 10.1126/scisignal. 2000568

Kogo, R., Shimamura, T., Mimori, K., Kawahara, K., Imoto, S., Sudo, T., et al. (2011). Long noncoding RNA HOTAIR regulates polycomb-dependent chromatin modification and is associated with poor prognosis in colorectal cancers. Cancer Res. 71, 6320-6326. doi: 10.1158/0008-5472.CAN-11-1021

Kondo, M., Suzuki, H., Ueda, R., Osada, H., Takagi, K., Takahashi, T., et al. (1995). Frequent loss of imprinting of the H19 gene is often associated with its overexpression in human lung cancers. Oncogene 10, 1193-1198. doi: 10.1378/chest.13-2736ů7.13

Korneev, S. A., Park, J. H., and O'Shea, M. (1999). Neuronal expression of neural nitric oxide synthase (nNOS) protein is suppressed by an antisense RNA transcribed from an NOS pseudogene. J. Neurosci. 19, 7711-7720.

Kotake, Y., Nakagawa, T., Kitagawa, K., Suzuki, S., Liu, N., Kitagawa, M., et al. (2011). Long non-coding RNA ANRIL is required for the PRC2 recruitment to and silencing of p15(INK4B) tumor suppressor gene. Oncogene 30, 1956-1962. doi: 10.1038 /onc. 2010.568

Kretz, M., Siprashvili, Z., Chu, C., Webster, D. E., Zehnder, A., Qu, K., et al. (2013). Control of somatic tissue differentiation by the long non-coding RNA TINCR. Nature 493, 231-235. doi: 10.1038/ nature 11661

Krystal, G. W., Armstrong, B. C., and Battey, J. F. (1990). N-myc mRNA forms an RNA-RNA duplex with endogenous antisense transcripts. Mol. Cell. Biol. 10, 4180-4191.

Kurukuti, S., Tiwari, V. K., Tavoosidana, G., Pugacheva, E., Murrell, A., Zhao, Z., et al. (2006). CTCF binding at the H19 imprinting control region mediates maternally inherited higher-order chromatin conformation to restrict enhancer access to Igf2. Proc. Natl. Acad. Sci. U.S.A. 103, 10684-10649. doi: $10.1073 /$ pnas. 0600326103

Lewis, A., and Murrell, A. (2004). Genomic imprinting: CTCF protects the boundaries. Curr. Biol. 14, R284-R286. doi: 10.1016/j.cub.2004.03.026

Li, Y. M., Franklin, G., Cui, H. M., Svensson, K., He, X. B., Adam, G., et al. (1998). The H19 transcript is associated with polysomes and may regulate IGF2 expression in trans. J. Biol. Chem. 273, 28247-28252. doi: 10.1074/jbc.273.43.28247
Liu, Z., Wang, W., Jiang, J., Bao, E., Xu, D., Zeng, Y., et al. (2013). Downregulation of GAS5 promotes bladder cancer cell proliferation, partly by regulating CDK6. PLOS ONE 8:e73991. doi: 10.1371/journal.pone.0073991

Lottin, S., Adriaenssens, E., Dupressoir, T., Berteaux, N., Montpellier, C., Coll, J., et al. (2002). Overexpression of an ectopic H19 gene enhances the tumorigenic properties of breast cancer cells. Carcinogenesis 23, 1885-1895. doi: 10.1093/carcin/23.11.1885

Luo, M., Li, Z., Wang, W., Zeng, Y., Liu, Z., and Qiu, J. (2013). Long noncoding RNA H19 increases bladder cancer metastasis by associating with EZH2 and inhibiting E-cadherin expression. Cancer Lett. 333, 213-221. doi: 10.1016/j.canlet.2013.01.033

Ma, C., Nong, K., Zhu, H., Wang, W., Huang, X., Yuan, Z., et al. (2014). H19 promotes pancreatic cancer metastasis by derepressing let-7's suppression on its target HMGA2-mediated EMT. Tumour Biol. 35, 9163-9169. doi: 10.1007/s13277-014-2185-5

Maenner, S., Blaud, M., Fouillen, L., Savoye, A., Marchand, V., Dubois, A., et al. (2010). 2-D structure of the A region of Xist RNA and its implication for PRC2 association. PLoS Biol. 8:e1000276. doi: 10.1371/journal.pbio.1000276

Martianov, I., Ramadass, A., Serra Barros, A., Chow, N., and Akoulitchev, A. (2007). Repression of the human dihydrofolate reductase gene by a non-coding interfering transcript. Nature 445, 666-670. doi: 10.1038/nature05519

Mercer, T. R., Dinger, M. E., and Mattick, J. S. (2009). Long noncoding RNAs: insights into functions. Nat. Rev. Genet. 10, 155-159. doi: 10.1038/nrg2521

Monnier, P., Martinet, C., Pontis, J., Stancheva, I., Ait-Si-Ali, S., and Dandolo, L. (2013). H19 lncRNA controls gene expression of the Imprinted Gene Network by recruiting MBD1. Proc. Natl. Acad. Sci. U.S.A. 110, 20693-20698. doi: $10.1073 /$ pnas. 1310201110

Moore, T., Constancia, M., Zubair, M., Bailleul, B., Feil, R., Sasaki, H., et al. (1997). Multiple imprinted sense and antisense transcripts, differential methylation and tandem repeats in a putative imprinting control region upstream of mouse Igf2. Proc. Natl. Acad. Sci. U.S.A. 94, 12509-12514. doi: 10.1073/pnas.94.23.12509

Mourtada-Maarabouni, M., Pickard, M. R., Hedge, V. L., Farzaneh, F., and Williams, G. T. (2009). GAS5, a non-protein-coding RNA, controls apoptosis and is downregulated in breast cancer. Oncogene 28, 195-208. doi: 10.1038/onc. 2008.373

Murrell, A., Heeson, S., and Reik, W. (2004). Interaction between differentially methylated regions partitions the imprinted genes Igf2 and H19 into parentspecific chromatin loops. Nat. Genet. 36, 889-893. doi: 10.1038/ng1402

Onyango, P., and Feinberg, A. P. (2011). A nucleolar protein, H19 opposite tumor suppressor (HOTS), is a tumor growth inhibitor encoded by a human imprinted H19 antisense transcript. Proc. Natl. Acad. Sci. U.S.A. 108, 16759-16764. doi: 10.1073/pnas.1110904108

Pandey, R. R., Mondal, T., Mohammad, F., Enroth, S., Redrup, L., and Komorowski, J., et al. (2008). Kcnqlotl antisense noncoding RNA mediates lineage-specific transcriptional silencing through chromatin-level regulation. Mol. Cell 32, 232-246. doi: 10.1016/j.molcel.2008.08.022

Pang, K. C., Frith, M. C., and Mattick, J. S. (2006). Rapid evolution of noncoding RNAs: lack of conservation does not mean lack of function. Trends Genet. 22, 1-5. doi: 10.1016/j.tig.2005.10.003

Pasmant, E., Laurendeau, I., Héron, D., Vidaud, M., Vidaud, D., and Bièche, I. (2007). Characterization of a germ-line deletion, including the entire INK4/ARF locus, in a melanoma-neural system tumor family: identification of ANRIL, an antisense noncoding RNA whose expression coclusters with ARF. Cancer Res. 67, 3963-3969. doi: 10.1158/0008-5472.CAN-06-2004

Pasmant, E., Sabbagh, A., Masliah-Planchon, J., Ortonne, N., Laurendeau, I., Melin, L., et al. (2011). Role of noncoding RNA ANRIL in genesis of plexiform neurofibromas in neurofibromatosis type 1. J. Natl. Cancer Inst. 103, 1713-1722. doi: 10.1093/jnci/djr416

Pauli, A., Valen, E., Lin, M. F., Garber, M., Vastenhouw, N. L., Levin, J. Z., et al. (2012). Systematic identification of long noncoding RNAs expressed during zebrafish embryogenesis. Genome Res. 22, 577-591. doi: 10.1101/gr.133009.111

Penaherrera, M. S., Weindler, S., Van Allen, M. I., Yong, S. L., Metzger, D. L., McGillivray, B., et al. (2010). Methylation profiling in individuals with RussellSilver syndrome. Am. J. Med. Genet. 152A, 347-355. doi: 10.1002/ajmg. a.33204

Poliseno, L., Salmena, L., Zhang, J., Carver, B., Haveman, W. J., and Pandolfi, P. P. (2010). A coding-independent function of gene and pseudogene mRNAs regulates tumour biology. Nature 465, 1033-1038. doi: 10.1038/nature09144 
Prensner, J. R., Iyer, M. K., Balbin, O. A., Dhanasekaran, S. M., Cao, Q., Brenner, J. C., et al. (2011). Transcriptome sequencing across a prostate cancer cohort identifies PCAT-1, an unannotated lincRNA implicated in disease progression. Nat. Biotechnol. 29, 742-749. doi: 10.1038/nbt.1914

Reeves, M. B., Davies, A. A., McSharry, B. P., Wilkinson, G. W., and Sinclair, J. H. (2007). Complex I binding by a virally encoded RNA regulates mitochondriainduced cell death. Science 316, 1345-1348. doi: 10.1126/science.1142984

Rinn, J. L., Kertesz, M., Wang, J. K., Squazzo, S. L., Xu, X., Brugmann, S. A., et al. (2007). Functional demarcation of active and silent chroatin domains in human HOX loci by noncoding RNAs. Cell 129, 1311-1323. doi: 10.1016/j.cell.2007.05.022

Rivkin, M., Rosen, K. M., and Villa-Komaroff, L. (1993). Identification of an antisense transcript from the IGF-II locus in mouse. Mol. Reprod. Dev. 35, 394-397. doi: $10.1002 / \mathrm{mrd} .1080350413$

Schmidt, L. H., Spieker, T., Koschmieder, S., Schäffers, S., Humberg, J., Jungen, D., et al. (2011). The long noncoding MALAT-1 RNA indicates a poor prognosis in non-small cell lung cancer and induces migration and tumor growth. J. Thorac. Oncol. 6, 1984-1992. doi: 10.1097/JTO.0b013e3182307eac

Shi, X., Sun, M., Liu, H., Yao, Y., and Song, Y. (2013). Long non-coding RNAs: a new frontier in the study of human diseases. Cancer Lett. 339, 159-166. doi: 10.1016/j.canlet.2013.06.013

Swiezewski, S., Liu, F., Magusin, A., and Dean, C. (2009). Coldinduced silencing by long antisense transcripts of an Arabidopsis Polycomb target. Nature 462, 799-802. doi: 10.1038/nature08618

Taft, R. J., Pang, K. C., Mercer, T. R., Dinger, M., and Mattick, J. S. (2010). Non-coding RNAs: regulators of disease. J. Pathol. 220, 126-139. doi: $10.1002 /$ path. 2638

Tano, K., and Akimitsu, N. (2012). Long non-coding RNAs in cancer progression. Front. Genet. 3:219. doi: 10.3389/fgene.2012.00219

Tripathi, V., Ellis, J. D., Shen, Z., Song, D. Y., Pan, Q., Watt, A. T., et al. (2010). The nuclear-retained noncoding RNA MALAT1 regulates alternative splicing by modulating SR splicing factor phosphorylation. Mol. Cell 39, 925-938. doi: 10.1016/j.molcel.2010.08.011

Tripathi, V., Shen, Z., Chakraborty, A., Giri, S., Freier, S. M., Wu, X., et al. (2013). Long noncoding RNA MALAT1 controls cell cycle progression by regulating the expression of oncogenic transcription factor B-MYB. PLoS Genet. 9:e1003368. doi: 10.1371/journal.pgen.1003368

Tsai, M. C., Manor, O., Wan, Y., Mosammaparast, N., Wang, J. K., Lan, F., et al. (2010). Long noncoding RNA as modular scaffold of histone modification complexes. Science 329, 689-693. doi: 10.1126/science.1192002

Tsang, W. P., Ng, E. K., Ng, S. S., Jin, H., Yu, J., Sung, J. J., et al. (2010). Oncofetal H19-derived miR-675 regulates tumor suppressor RB in human colorectal cancer. Carcinogenesis 31, 350-358. doi: 10.1093/carcin/bgp181

Völkel, P., and Angrand, P. O. (2007). The control of histone lysine methylation in epigenetic regulation. Biochimie 89, 1-20. doi: 10.1016/j.biochi.2006. 07.009

Völkel, P., Dupret, B., Le Bourhis, X., and Angrand, P. O. (2015). Diverse involvement of EZH2 in cancer epigenetics. Am. J. Transl. Res. 7, 175-193.

Wang, J., Liu, X., Wu, H., Ni, P., Gu, Z., Qiao, Y., et al. (2010). CREB up-regulates long non-coding RNA, HULC expression through interaction with microRNA372 in liver cancer. Nucleic Acids Res. 38, 5366-5383. doi: 10.1093/nar/gkq285

Wang, K. C., Yang, Y. W., Liu, B., Sanyal, A., Corces-Zimmerman, R., Chen, Y., et al. (2011). A long noncoding RNA maintains active chromatin to coordinate homeotic gene expression. Nature 472, 120-124. doi: 10.1038/nature09819

Wang, X., Arai, S., Song, X., Reichart, D., Du, K., Pascual, G., et al. (2008). Induced ncRNAs allosterically modify RNA-binding proteins in cis to inhibit transcription. Nature 454, 126-130. doi: 10.1038/nature06992
Wang, Y., Xu, Z., Jiang, J., Xu, C., Kang, J., Xiao, L., et al. (2013). Endogenous miRNA sponge lincRNA-RoR regulates Oct4, Nanog, and Sox2 in human embryonic stem cell self-renewal. Dev. Cell. 25, 69-80. doi: 10.1016/j.devcel.2013.03.002

Wapinski, O., and Chang, H. Y. (2011). Long noncoding RNAs and human disease. Trends Cell. Biol. 21, 354-361. doi: 10.1016/j.tcb.2011.04.001

Weber, M., Hagège, H., Murrell, A., Brunel, C., Reik, W., Cathala, G., et al. (2003). Genomic imprinting controls matrix attachment regions in the Igf2 gene. Mol. Cell. Biol. 23, 8953-8959. doi: 10.1128/MCB.23.24.8953-8959.2003

Willingham, A. T., Orth, A. P., Batalov, S., Peters, E. C., Wen, B. G., Aza-Blanc, P., et al. (2005). A strategy for probing the function of noncoding RNAs finds a repressor of NFAT. Science 309, 1570-1573. doi: 10.1126/science.1115901

Wilusz, J. E., Sunwoo, H., and Spector, D. L. (2009). Long noncoding RNAs: functional surprises from the RNA world. Genes Dev. 23, 1494-1504. doi: 10.1101/gad.1800909

Xiang, J. F., Yin, Q. F., Chen, T., Zhang, Y., Zhang, X. O., Wu, Z., et al. (2014). Human colorectal cancer-specific CCAT1-L lncRNA regulates longrange chromatin interactions at the MYC locus. Cell Res 24, 513-531. doi: 10.1038/cr.2014.35

Yang, F., Bi, J., Xue, X., Zheng, L., Zhi, K., Hua, J., et al. (2012). Up-regulated long non-coding RNA H19 contributes to proliferation of gastric cancer cells. FEBS J. 279, 3159-3165. doi: 10.1111/j.1742-4658.2012.08694.x

Yang, F., Zhang, L., Huo, X. S., Yuan, J. H., Xu, D., Yuan, S. X., et al. (2011). Long noncoding RNA high expression in hepatocellular carcinoma facilitates tumor growth through enhancer of zeste homolog 2 in humans. Hepatology 54, 1679-1689. doi: 10.1002/hep. 24563

Yap, K. L., Li, S., Muñoz-Cabello, A. M., Raguz, S., Zeng, L., Mujtaba, S., et al. (2010). Molecular interplay of the noncoding RNA ANRIL and methylated histone $\mathrm{H} 3$ lysine 27 by polycomb CBX7 in transcriptional silencing of INK4a. Mol. Cell 38, 662-674. doi: 10.1016/j.molcel.2010.03.021

Yoon, J. H., Abdelmohsen, K., Srikantan, S., Yang, X., Martindale, J. L., De, S., et al. (2012). LincRNA-p21 suppresses target mRNA translation. Mol. Cell 47, 648-655. doi: 10.1016/j.molcel.2012.06.027

Zhang, K., Sun, X., Zhou, X., Han, L., Chen, L., Shi, Z., et al. (2015). Long noncoding RNA HOTAIR promotes glioblastoma cell cycle progression in an EZH2 dependent manner. Oncotarget 6, 537-546.

Zhao, J., Sun, B. K., Erwin, J. A., Song, J. J., and Lee, J. T. (2008). Polycomb proteins targeted by a short repeat RNA to the mouse X chromosome. Science 322, 750-756. doi: 10.1126/science.1163045

Zhao, X., Tang, Z., Zhang, H., Atianjoh, F. E., Zhao, J. Y., Liang, L., et al. (2013). A long noncoding RNA contributes to neuropathic pain by silencing Kcna2 in primary afferent neurons. Nat. Neurosci. 16, 1024-1031. doi: 10.1038/nn.3438

Zhuang, M., Gao, W., Xu, J., Wang, P., and Shu, Y. (2014). The long non-coding RNA H19-derived miR-675 modulates human gastric cancer cell proliferation by targeting tumor suppressor RUNX1. Biochem. Biophys. Res. Commun. 448, 315-322. doi: 10.1016/j.bbrc.2013.12.126

Conflict of Interest Statement: The authors declare that the research was conducted in the absence of any commercial or financial relationships that could be construed as a potential conflict of interest.

Copyright (C) 2015 Angrand, Vennin, Le Bourhis and Adriaenssens. This is an openaccess article distributed under the terms of the Creative Commons Attribution License (CC BY). The use, distribution or reproduction in other forums is permitted, provided the original author(s) or licensor are credited and that the original publication in this journal is cited, in accordance with accepted academic practice. No use, distribution or reproduction is permitted which does not comply with these terms. 